PART THREE

\title{
Toxic Beauty
}





\section{6 \\ The X-Ray Sublime}

The world is suffering for our success.

-EDWARD BURTYNSKY, NO MAN'S LAND

Whereas chapters 1 and 2 analyzed error and failure as constructs of human art and philosophy, and chapters 3 through 5 did so in digital aesthetics, this chapter and the next analyze man-made waste and environmental deterioration as a direct result of the high-tech industries. ${ }^{1}$ In the same way that glitch and error are normatively concealed from view, only returning to the foreground of experience through actual failure or critique, contemporary images of man-made waste discussed in this chapter and the next foreground the trash otherwise hidden from, but directly generated by "us" - First World consumers. The trash of the so-called innovation age is our collective, shameful error.

The cultural failure to adequately care for the earth (and one another) appears in the images of Part III as a heady noise entangled in an even more disturbing visual beauty. This chapter focuses on framing man-made waste through the classic aesthetic concept of the sublime. It also draws on the landscape photography of the internationally renowned Canadian photographer Edward Burtynsky. ${ }^{2}$ Contrary to numerous critics' suggestions that Burtynsky's work is pure spectacle, this chapter argues that it is indeed visually beautiful, while also driving a deeper critique. By exposing privileged audiences to previously undetected scenes of environmental destruction, Jennifer Peeples argues, Burtynsky opens the door for "social, cultural and/or political analysis, even if it simply prompts the question, 'Why haven't I known this exists?'”

The chapter begins with a computer-animated example of trash characteristic of our culture's baleful yet deeply mythological relationship to the environment. This is shadowed by a brief introduction to Burtynsky, followed by a return to Peeples's work and a lengthy exegesis on classical and contemporary conceptions 
of the Sublime, a concept central to this and the following chapter. In the last part of the chapter, Burtynsky's work is connected to what I call the "X-ray sublime", a twenty-first-century updating of the classical concept. ${ }^{4}$ While breakdown and destruction are indigenous to any environment, this chapter inquires: What does it mean to make beautiful images of otherwise horrifying environmental conditions? What kind of aesthetic sublime do we encounter at the dawn of the twentyfirst century, and how do ethical and cognitive failures shape its contours?

\section{FUTURE TRASH}

Beginning several hundred years into the future, the 2008 Pixar film Wall.E (directed by Andrew Stanton), opens with a shot of its protagonist, Wall•E, seen in the midst of his job activities, piling and compacting exceedingly high towers of human trash. Wall•E, whose name is an acronym for "Waste Allocation Load Lifter Earth," does not seem to mind the task, perhaps he even enjoys it. Regardless, he is acting in a frenzy, obsessively and compulsively, without pause or patience. The turmoil is not normal, the film implies, there is a glitch in his software making him act this way, the nature of which, Timothy Morton notes, remains unclear. ${ }^{5}$ Some may identify with this militant fanaticism and relentless drive to clean up his home - the earth-by picking up garbage but, unfortunately, such a drive is alien to the majority of us. Consider too that Wall•E's obsessive compulsive drive to pick up heaps of trash is construed by the film as an error.

The film's opening scene thus invites reflection on the markedly human relationship between technological innovation and destruction. It is precisely this appeal to "humanness", Morton suggests, that Wall•E is searching for in a "discarded Rubix cube, a Hello Dolly video, or a tiny sprout in a flowerpot." ${ }^{6}$ It is also likely that some viewers, like myself, sat in a dark theater pining for Wall•E to succeed in finding an advanced technological solution to ecological problems (and maybe even social and political injustices), thus letting us humans off the hook. Such fantasies of absolution point precisely to the ethical failures addressed in this chapter.

\section{Towards an Ethical Ecology}

We may take instruction from studies in ecology where "ecology" is understood as distinct from the environment or landscape. The German noun Oecologie (commonly spelled Ökologie) was coined by the zoologist Ernst Haeckel in the 186os, combining the Greek root oikos, meaning household, or habitat, and logos (knowledge). The term was utilized as a way of describing not just a wild and unpopulated place called the environment, but also an environment that was just as much a "home" to humans, seemingly amending earlier associations with the notion of "environment" as a space of cultural non-existence. ${ }^{7}$ In the same moment we began to see ourselves as separate from the world, Dominic Pettman argues, we 


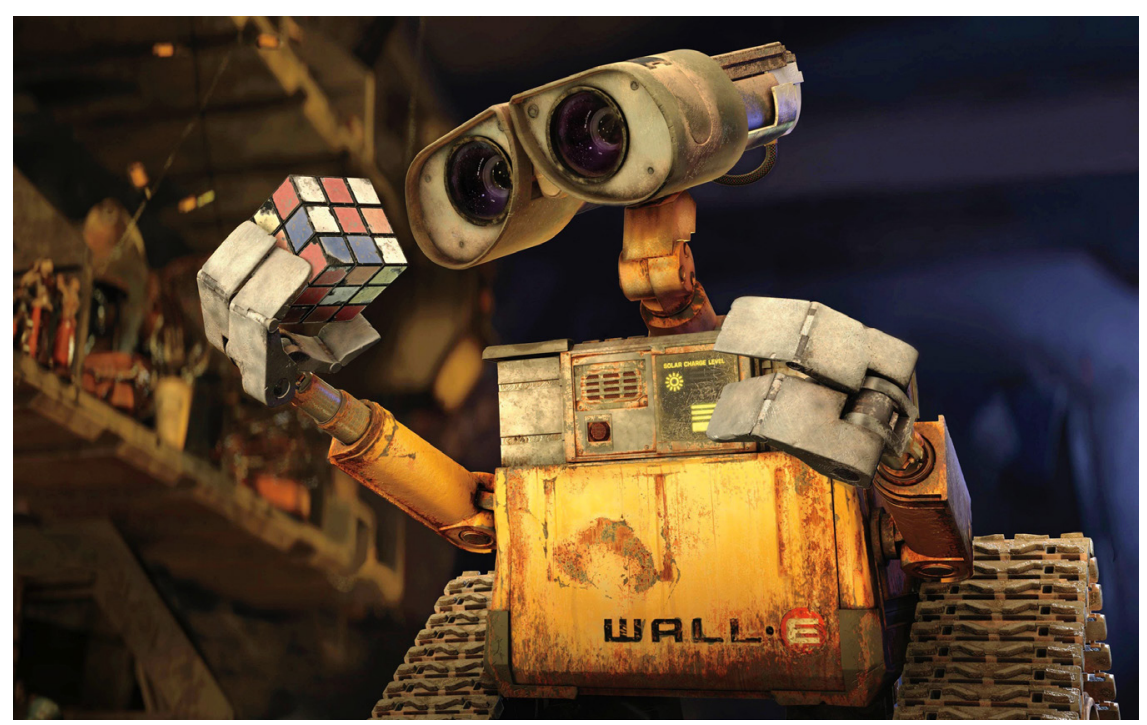

FIGURE 28. Pixar's Wall•E (2008). Stills. The film's robot protagonist looking to solve ecological problems.

began to see the world itself as an object of ownership. This proprietary ethos, he argues, has led to extensive manipulations and attempts to ravage and control the planet, evidence for which we can find everywhere around us. ${ }^{8}$ And while I am in agreement with this, I also wish to shift this focus to how and what responsible ecological ownership might look like.

Responsibility implies care. Impressive man-made developments in industry, architecture, and public culture may dwarf individual agency, but if the earth is our collective household (whether we use the word "environment" or "ecology"), it is therefore also the home to which we all belong and share accountability for. Heidegger proposed this in his 1927 reconsideration of the Latin myth of Cura, noted in the Introduction. To briefly rehash: Cura is crossing a river, after which she pauses to mold some clay. While selecting a name for her creation, she is caught in a dispute between Heaven (Jupiter) and Earth (Gaia). Saturn, god of time, decides that Heaven will have the clay's spirit in death, and Earth will have it in life. Because Cura is the creator of the beings, she will keep them in her care while they live, with the name "human beings." Insofar as we are alive, we live in and through care. Care is intrinsic to being; a prerequisite for making peace with one's individual being (Dasein) in the world, a collective to which one also belongs in and with ("alongside"). Collective concern becomes the key to living well for oneself. The paradox plays into Heidegger's larger ethical demand to question not only that one cares for a world that brought forth being, but also, how. ${ }^{9}$ 
The how determines the quality of care. How do we actually address the urgency of ecological toxicity and e-waste? To begin, we must understand humans and technology as coextensive, co-evolutionary systems. If high-tech industries are creating toxins and poisoning the air and water, they do so because people make decisions to operate in borderline conditions, to exploit workers without rights or unions, to use raw materials of poor quality and precarious origin, and dispose of by-products and toxins irresponsibly. The environment is not falling apart because plastic is evil. It is failing because we fail it, a cumulative outcome of each person's failure to question the consequences of their actions. On a daily basis, millions of individuals make seemingly negligible decisions regarding the environment. Every single gesture, Chris Jordan (chapter 7) points out, accumulates into a much larger collective liability. ${ }^{10}$ I do not intend to exclusively scapegoat individuals-versus the corporate and government entities that fail to regulate such activities - I highlight this only because it is an immediate and accessible starting point. Moreover, it is also individual people who make up these corporate and government bodies. Burtynsky's work provides a set of visual materials to further assess this tension.

\section{EDWARD BURTYNSKY}

Born in Canada in 1955, as a child, Burtynsky was fascinated with industrial images. His father worked at the local General Motors factory and spent his leisure time painting and engaging in amateur photography. Not surprisingly, by the age of seven, Edward had found a love for painting landscapes. ${ }^{11}$ At eleven years old, he received his first $35 \mathrm{~mm}$ camera and access to a darkroom. By the age of twenty, he was taking night school courses in photography and studying graphic arts at college. ${ }^{12}$ After enrolling in Ryerson University's esteemed photography program in Toronto, Burtynsky benefited from the instruction of Canadian photographer Robert Gooblar (1945-97). Gooblar introduced him to hybrid practical and conceptual experiments, a dynamic pedagogy that the Faculty of Communication and Design (FCAD) at Ryerson is known for. In one such experiment, Gooblar sat in the studio with a seashell in one hand with a light suspended above him. For an hour, he spoke about the seashell, its geometry, translucence, the kinds of images it conjured up for him, and the disparate ways in which one could approach even the simplest of objects. Also at Ryerson, Burtynsky learned to use a $4 \times 5$ medium format camera. ${ }^{13}$ The apparatus "hit a direct chord in me," he explains, possibly due to its capacity to capture opulent detail in a medium typically associated with documentary and social realism, or perhaps it was the slow pace and patience required to work with it. ${ }^{14}$

During his studies, he also developed what has become his trademark X-raylike capacity to detect the "negative spaces" in the world around him. In one illustrative example, he was assigned the task of photographing the "human presence in the landscape." ${ }^{15}$ While examining the urban landscape of downtown Toronto 


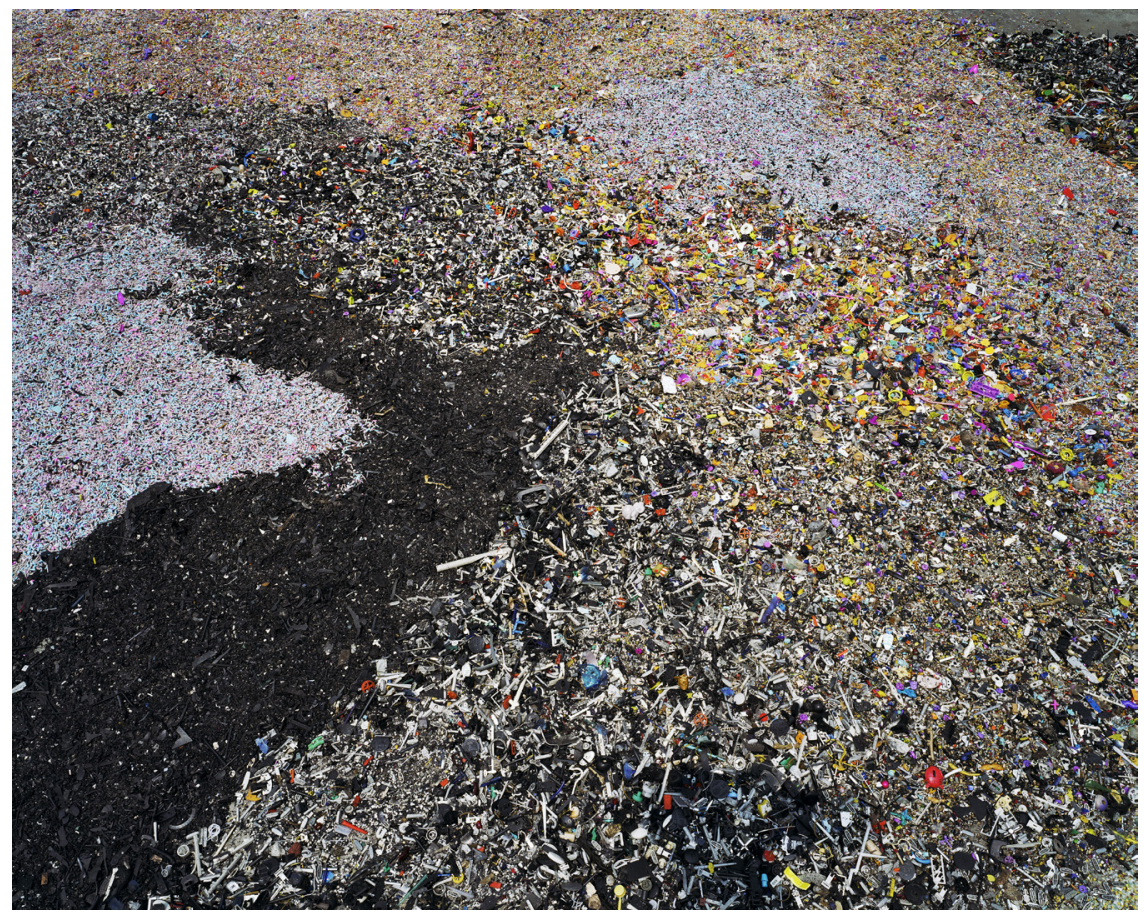

FIgure 29. Edward Burtynsky, China Recycling \#8, Plastic Toy Parts Guiyu, Guangdong Province (2004). ( Edward Burtynsky, courtesy of Nicholas Metivier Gallery, Toronto.

that fuses with the Ryerson campus, Burtynsky took special note of the compact but large concrete and quartz architecture, especially the buildings serving the nearby financial district. In these structures he saw "negative spaces" - not large slabs of concrete protruding from the ground, but rather, images of absence. The negative space in an image is typically the "background" or empty space, but, as any design student will tell you, it is also an active space. All of the glass, sand, and raw materials used in these structures, he reasoned, arrived from somewhere else, another ecology that is depreciated yet ever so subtly implied in the striking presence of these hefty counterparts. Seemingly eschewing postmodern fashions of the time, Burtynsky henceforth adopted a retrogressive modernist agenda, questioning the linear history and ecological origins of the raw materials used to build the skyscrapers surrounding him. Because the stones "appear to have been taken out of a quarry one block at a time," he reasoned, somewhere there had to be an inverted complementary structure. ${ }^{16}$ His inquiries sent him in search of evidence of this "reciprocal action on the environment," and in Vermont and rural Ontario he found it in the shape of what he calls "inverted skyscrapers"-multilevel, vertical excavations in the Earth's crust. ${ }^{17}$ While this chapter does not focus on his 
photographs of these inverted architectures at length, they remain helpful in highlighting Burtynsky's early interests in the visual beauty of residual, leftover landscapes, compounded by a sensibility already tuned towards the inverted and negative. Further, we also see evidence of the artist's attunement to media archaeology, in both the theoretical (media studies) and practical (actual archaeology) sense. By translating the concept of negative space from graphic design to ecology, Burtynsky brought to light what was not visible in the landscape, but intrinsic to its material history.

Aside from his images of the Vermont and Ontario quarries, Burtynsky is also known for his photographs of global waste and the ruins of industrial and postindustrial cultures, including shipbreaking practices in Bangladesh, e-waste recovery in China, mineral-polluted lakes in Canada, oil-pollution in the Gulf of Mexico, and urban renewal projects and e-waste in Shanghai..$^{18}$ He typically uses a large-format $(8 \times 10)$ Hasselblad camera, which lends a visual richness to his work and confirms his preference for stylized surfaces with rich detail, color, and resolution. Although the resulting images-typically printed in extra-large format-are extremely beautiful, they have consistently been received as exploitive renderings of human trash and environmental destruction, leveraged for the sake of lavish spectacle. But why would Burtynsky want to glamorize waste and toxicity by beautifying these shameful sites? The answer lies in what I term the "X-Ray sublime," a series of aesthetic and philosophical contradictions that draw from the classical concept of the sublime, with its roots in a complex play between the beautiful and the horrific. In the next section, I provide a historical context for this philosophical legacy, allowing me to situate the X-ray sublime alongside Burtynsky's contemporary practice. Following this, I return to the socioeconomic factors leading to e-waste and the ways in which Burtynsky's images intersect with them.

\section{THE SUBLIME}

In aesthetic philosophy, the concept of the Sublime has traditionally implied a liminal space of uncertainty and confusion, whether between pleasure and pain, madness and reason, or chaos and control. Deriving from the Latin sublimis, the term denotes a "looking up from," which is to say it already signals a hierarchical tension between figure and ground. The Latin word limen connotes a threshold between conscious and unconscious where, as a result of many years of cultural practice, the former is privileged over the latter. This basic tension between the two forces has been preserved throughout the history of aesthetic philosophy, albeit in divergent ways. To elucidate how and why a contemporary offshoot like the "X-ray sublime" arrives at the tail end of this trajectory, I provide an exegesis of the concept from its early development in Plato and Longinus, through Enlightenment instantiations in Burke and Kant, to the present, when I reconnect it with Burtynsky's work. 


\section{The Proto-Sublime}

Plato's Ion (380 B.C.E.) is the only one of Plato's dialogues devoted exclusively to art. It addresses the possession of an artist by god and theorizes this (divine) madness as immanent to the creative process. This occurs primarily through Socrates' arguments with Ion to determine that poets are unconscious and void of reason. The text proposes a model of creative activity wherein sublime creation is analogous to madness, yet it is still placed at the center of creative practice-even if it will later be dismantled by the rational mind. At the same time, creative madness is in no way glorified in the text. Plato draws a clear distinction between reason and creative madness: in order to create at all, an artist or poet must be mad: "there is no invention in him until he has been inspired and is out of his senses, and the mind is no longer in him." ${ }^{19}$ Elsewhere Plato reaffirms this same distinction between rational, scientific practice (technē), and the whims of poiesis. ${ }^{20}$ Whereas the former involves a well-measured, logical relation between cause and effect, the latter is relegated to the mysteries of the soul (artistic practice) and deemed unstable in knowledge-formation. ${ }^{21}$ The distinction is key because, as we will see, in the contemporary sublime, level-headed technical activities no longer retain their link to logic and reason. Instead, they become confusing and "out of their senses." That is, noisy and unstable. ${ }^{22}$

The relationship between reason and (creative) madness is taken up again by Longinus in the first century C.E. in On the Sublime, where he identifies five sources of sublimity: "great thoughts, strong emotions, certain figures of thought and speech, noble diction, and dignified word arrangement." For Longinus, the sublime was more than merely persuasive or madly inspired rhetoric, it was also inflicted with a sense of the impossible, connected to a "certain excellence, distinction, and expression" extending beyond the concrete or verifiable. ${ }^{23}$ And even though the sublime is impossible to attain or master, he argued, it nonetheless draws from an "irresistible force" that many cannot resist. ${ }^{24}$ Longinus invokes the image of a lightning bolt to illustrate the effect. A sudden flash of sublimity throws one into an immediate trance, scattering everything that came before and after it. ${ }^{25}$ The sublime is thus proposed as an aesthetic concept with a not-so-visible transformative force at its center. In the same way, a flash of lightning can in an instant transform a dark landscape into an inverted image of light. In sum, for thousands of years, the sublime has been linked to a poetic sense of the world that is greater than, and beyond, scientific understanding.

\section{The Classical Sublime}

Jumping ahead several centuries, English philosopher Edmund Burke introduced a full-bodied theory of the sublime in his Gothic-inspired Philosophical Enquiry into the Origin of Our Ideas of the Sublime and the Beautiful (1757). Burke shed light on the ways in which combined feelings of terror and delight fuse in the sublime, typically when one confronts the powerful or threatening forces of Nature. ${ }^{26}$ 
Things like the roar of the ocean and poisonous snakes evoke astonishment and terror simultaneously. ${ }^{27}$ All-powerful and external to oneself, Nature triggers "the drive for self-preservation." ${ }^{28}$ Since a sublime object may evoke the overwhelming likelihood of death, it must be distinct from mere pain. Amanda Boetzkes quotes Burke: "The only difference between pain and terror is that things which cause pain operate on the mind, by the intervention of the body; whereas things that cause terror generally affect the bodily organs by the operation of the mind suggesting danger." ${ }^{29}$ Sublime satisfaction derives from the exertion of the mind as it grapples with its palpable encounter with mortality. However, the fact that it will not actually result in death-one has merely come face to face with the idea of death-results in pleasure. The experience is nonetheless construed as transformative because, as the feeling of terror dissipates and the "burden of physical pain and threat" ${ }^{\prime \circ}$ is removed, the subject is suddenly liberated in the acknowledgement of recovery from this temporary loss of control. ${ }^{31}$ In recognizing this process, a subject presumably transforms ("transcends") the limits of one's mental faculties, therein experiencing cognitive delight. ${ }^{32}$

We can now understand the sublime as an aesthetic condition ensuing between subject and object, an "atmosphere" as the Greeks proposed, in which nature or some state of it (art will later assume this role) invokes an experience of terror, acting to weaken the individual sense of autonomy and control, but is ultimately overcome by another human capacity for self-preservation. In this way, the sublime must be understood as distinct from classical aesthetic theories of the beautiful. Burke differentiated between the two as follows: beauty can be found in small objects, things that are smooth, delicate, clean, fair, mild in color, and excite "the passion of love." The sublime, in contrast, is typified by vastness, privation, difficulty, infinity, magnitude, and magnificence. If it is capable of evoking "terror" and the kind of destabilizing fears noted above, an object or phenomena can be a source of the sublime, even if it results in pleasure, as the beautiful must always do. ${ }^{33}$

Shortly after Burke, Immanuel Kant introduced another systematic inquiry into the sublime. His interventions catalyzed nothing short of a paradigm shift in modern philosophy. This cannot be overstated. In his work, subjectivity moved to the fore of the concept of the sublime because he refreshingly validated a subject's experience, limited only by the impossibility of knowing the essence of an external object or thing in-itself (such as Nature). Kant writes, "true sublimity must be sought only in the mind of the judging subject, and not in the object of nature that occasions this attitude by the estimate formed of it." ${ }^{\prime 34}$ In short, he proposes a total inversion of classical thought. ${ }^{35}$ By moving away from traditional "object-focused" considerations of the sublime to focus instead on how aesthetic experience occurs in the subject, Kant's approach might at first resemble Plato's concern with an artist's madness, but this is far from the case. Plato fundamentally distrusted the madness of the poet and his creative process, whereas Kant placed this disorientation at the heart of aesthetic experience. 
Like Burke, Kant also distinguished between the beautiful and the sublime. In his 1790 Critique of Judgment, Kant argued that the beautiful is associated with "appearances," the smallness and brightness of ornamental things like color, décor, surface shine, and is "directly attended with a feeling of the furtherance of life." 36 However, while such surface phenomenon like color could support the category of the beautiful, in themselves they could only ever be secondary attributes; always already subordinate to "higher forms" of truth, meaning, and order (and here one does detect a trace of Platonism). Where the beautiful maintains clear boundaries between form and object, ${ }^{37}$ the aesthetic sublime, in contrast, is connected to a temporary cognitive breakdown expressed as fear and terror. The aesthetic sublime, Kant writes, "contravene[s at] the ends of our power of judgement[,] .. . ill-adapted to our faculty of presentation, and to be, as it were, an outrage on the imagination, and yet it is judged all the more sublime on that account." ${ }^{8}$ In short, it does not fit nicely into aesthetic experience at all, as the beautiful does so well, but is instead valued by its very incapacity to do so. Kant eventually accepted some forms of beauty into the sublime, though Burke did not. For the latter, beauty was merely pleasing but not capable of sublimity. In this chapter's analysis, the beautiful is taken as a surface aesthetic and as capable of integration with the sublime, especially in the X-ray sublime where, as we will see, it upstages the functioning of reason.

Kant's aesthetic, or "dynamic" sublime, as he referred to it, is central to understanding Burtynsky's work. ${ }^{39}$ The concept, as explained above, articulates an experience where there is an apparent transgression of the limits of reason and dissolution of the boundaries between it and external phenomena, coupled with an intrinsic link to Nature's beauty and awe. In the sublime, Kant explains, "it is rather in its chaos, or in its wildest and most irregular disorder and desolation ... that nature chiefly excites the ideas of the sublime." ${ }^{\circ 0}$ A hurricane or, to cite Kant's examples, "mountain masses towering one above the other in wild disorder, with their pyramids of ice, or ... the dark tempestuous ocean" invoke this dual force of fear and awe, but only insofar as one contemplates them through the imagination ("without any regard to their form, the mind abandons itself to the imagination"). Both fear and awe are necessarily constitutive of the concept, albeit void of any real danger. If imagination and reason work together to produce this sublime experience then, ultimately, the mind "feels itself elevated in its own estimate of itself." ${ }^{41}$ That is to say, reason and understanding reconcile the imagination from having sought to exceed its own limits. If the sublime bears an implicit threat of fear, reason brings the mental faculties back into balance by distinguishing between simulated and real danger. The sublime experience necessarily involves reason's laboring to master the faculty of the imagination. It is crucial to recognize that, for Kant, it is the faulty of reason that rescues the subject from the mental overload experienced by the imagination's reach towards the infinite, a reach that engendered an initial state of cognitive oscillation, experienced as the threat of the 
sublime, but is eventually reigned back in by the faculty of reason. Put differently, the imagination reaches a limit that only reason can acknowledge, not to master or control it, but to acknowledge it and, as such, recognize its own drive for selfpreservation as a form of self-congratulatory pleasure..$^{42}$

To summarize, Kant's pivotal intervention in the history of the sublime was to reconceive it as a condition of subjective experience, existing in the mental faculties of the viewer, and not a condition of any so-called objective, external world. The Kantian sublime induces an unhinged state of mind in the subject, triggered by worldly representations that occupy the energies of both the imagination and reflective judgment, but are ultimately appeased by the latter. ${ }^{43}$ Henceforth, when I refer to images as sublime, I am implicitly referring to this lineage, ending with Kant's reordering of aesthetic relations, and not a formal set of properties intrinsic to any object or work of art. ${ }^{44}$

When I use the term "X-ray sublime," I have in mind something else. Namely, an inverted, X-ray situation. Decades after Kant, aesthetic philosophers adhered to his views. Over the past half century, however, critical theorists (e.g., poststructuralists, deconstructionists, and postmodernists) have diverged from this orthodoxy. One of the key points of contention is the last step, where, according to Kant, the faculty of reason steps in to save the day, rescuing the imagination from attempting to move too far beyond the limits of understanding. For many intellectuals-the late Gilles Deleuze and myself included - this last step is too clean; too neat and tidy for a world of constant breakdown and uncertainty. Deleuze's late aesthetic theory, noted in the last chapter, is connected to my concept of the X-ray sublime as follows: drawing on Freud's theory of hysteria, Deleuze proposes that reason fails to recuperate the imagination. In Deleuze's reconceptualization of the sublime, Daniel W. Smith explains, one's "entire structure of perception ... is in the process of exploding ... [ one] can no longer apprehend successive parts ... no longer recognize what the thing is." ${ }^{45}$ Rolf Tiedemann identifies a similar refusal of (dialectic) closure in his discussion of Walter Benjamin's "dialectics at a standstill." ${ }^{4}$ The failure to provide resolution is also at the heart of my concept of the X-ray sublime, which turns on the inversion of classical and modern aesthetic pursuits for unification and cohesive symbolization. Put differently, the X-ray sublime does not overcome itself but instead lands in constant and perpetual chaos; the "incompossible" in Benjamin's work, as theorized by Judith Butler (see the Introduction); Ryan Trecartin's ambivalence; and here, our relationship to our own trash.

\section{BURTYNSKY'S X-RAY SUBLIME}

From aggressive public and private advertising to the cheap and unethical overproduction of transitory commodities, waste figures prominently in psychic and social life. It goes without saying that landscapes did not always look like this. The history of landscape photography tells us as much beginning with classical depictions of 
wonder and awe, to "feats" of industrial progress. Chapter 7 addresses this history in more detail, including the work of Carleton Watkins, August Sander, Margaret Bourke-White, and Harold Edgerton. Unlike these precursors, however, Burtynsky's landscapes do not convey a modern ethos of power and triumph. Rather, he offers a more restrained, distant, and arguably balanced point of view. Both success and failure come into a complex conversation in his work, which depicts the waste and trash of the contemporary world in beautiful tones and textures.

Burtynsky was also acquainted early on with the images created by the wellknown Brazilian photographer and economist Sebastião Salgado, who photographed shipbreaking in Bangladesh eleven years before him, after fleeing Brazil's politically repressive climate in 1969. Salgado's work focuses on issues of human labor, alienation, migration, and exploitation, evoking concern with the precariousness of human life. While these themes are also present in Burtynsky's work, they are secondary to his primary interest in capturing the patterns of oil, water, metal, or other objects moving through the landscape. ${ }^{47}$ Three sets of Burtynsky's photographs are discussed here: his images of shipbreaking in Bangladesh; e-waste in China; and his more recent aerial photography in the Water series.

\section{Shipbreaking Spectacles}

The multi-billion-dollar shipbreaking industry thriving on the beaches of Pakistan and Bangladesh is simply not a part of the reality with which most First World residents are acquainted. For the shipbreaking industry, however, dismantling massive oil tankers has been both a booming success and a horror show. Up until the latter part of the twentieth century, dismantling ships tended to occur in the ports of developed countries like the United Kingdom and the United States, "where the disposal of ships [was] regulated to protect workers and the environment." ${ }^{48}$ But things have changed. In 1965, a ferocious storm left a giant cargo ship beached on the pristine coast at Bhatiari, a city just to the west of Chittagong in Bangladesh. ${ }^{49}$ Locals immediately began stripping the ship of anything they could use, recycle, or re-style. Moreover, since Bangladesh has no iron mines, the masses of steel that the ship was built from became invaluable to its economy.

Almost half a century later, the majority of the world's ships are dismantled on the shores of Bangladesh, India, China, and Pakistan, countries "subject to less control and inspection" and precarious if any enforcement of labor laws. ${ }^{50}$ Here, tankers and other ships are run onto the beach and dismantled at low tide "without proper installations and equipment." ${ }^{51}$ For many, such "beaching" has proven a lucrative industry, providing thousands of tons of steel for construction rebar at "rock-bottom prices," ${ }^{2}$ which impoverished countries like Bangladesh could not otherwise afford. A single tanker can yield up to 50,000 meters of copper cable, $35,000 \mathrm{~kg}$ of aluminum anodes, $20,000 \mathrm{~kg}$ of zinc, and tens of thousands of liters of lubricating hydraulic oil, used for fuel. Even the gummy residues left over in empty fuel tanks are mixed with sand and compressed into logs for use in cooking fires. ${ }^{53}$ 


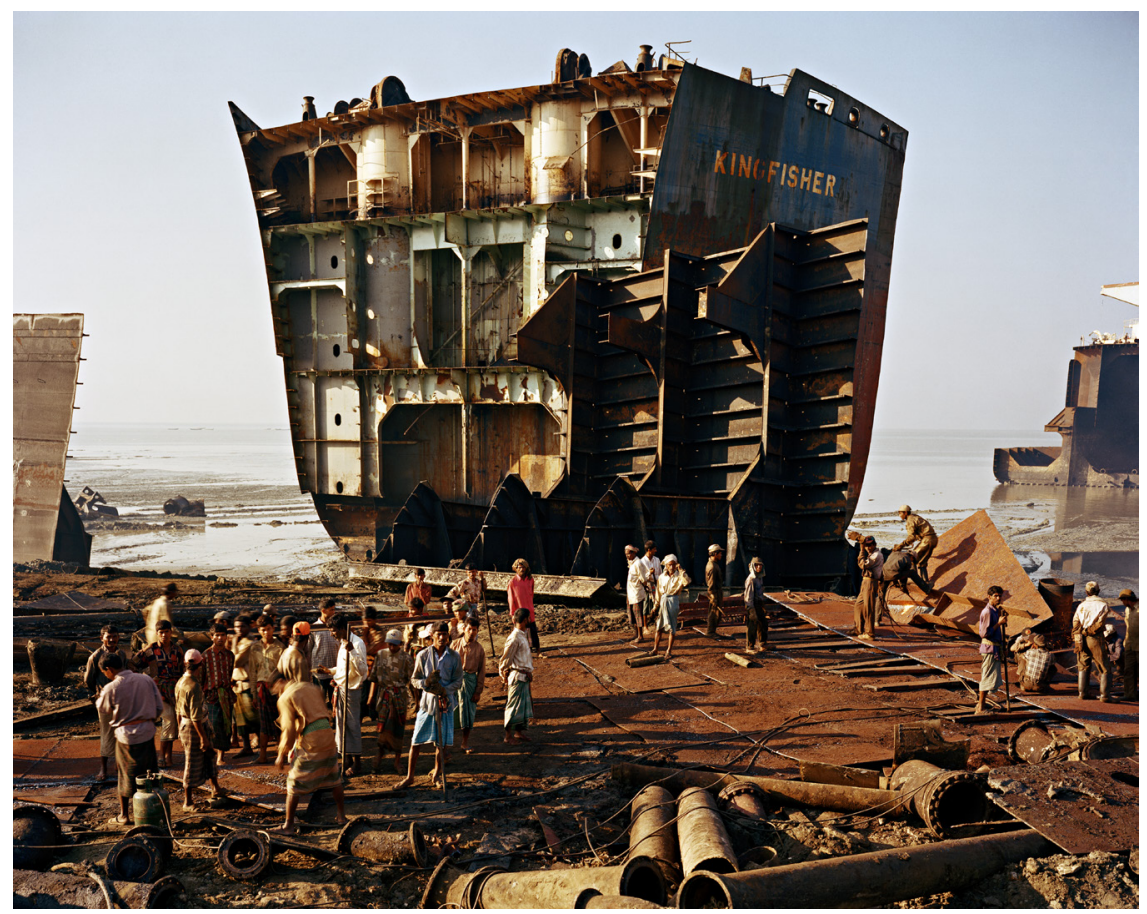

FIGURE 30. Edward Burtynsky, Shipbreaking \#04 (2000). A breathtaking image of the highly precarious shipbreaking practices in Pakistan and India. (C) Edward Burtynsky, courtesy of Nicholas Metivier Gallery, Toronto.

In short, every bolt, bar, and bathtub is recycled. In the 2010s, over 80 percent of the iron and steel used in Bangladesh came from forty-five shipbreaking yards along the Chittagong coast. ${ }^{54}$ According to Global Marketing Systems (GMS), Chittagong produces "around 1.3 million tons of finished rods" annually, all of which contribute to the country's development. 55

As noted, the shipbreaking industry now extends well beyond Chittagong. Soon after Chittagong's lead in the late 1960s, ships began to be beached in Alang, in India, which is now, arguably, the "leading ship-recycling yard in the world, catering to nearly $90 \%$ of India's ship recycling activity." ${ }^{56}$ Pakistan also got into the game early on, in the 1970s, and became a competitor to India by the beginning of the 1980s. On Gadani Beach in Pakistan, about thirty-five miles west of Karachi, old ships from around the world are beached, sometimes up to a hundred ships at a time. Once they arrive, workers are responsible for hauling them up onto the sand as far as they will go, until a team of workers arrives on board to dismantle and mine the hulk for usable parts. All of this also amounts to employment opportunities for citizens. Although numbers vary between sources, it is estimated that 


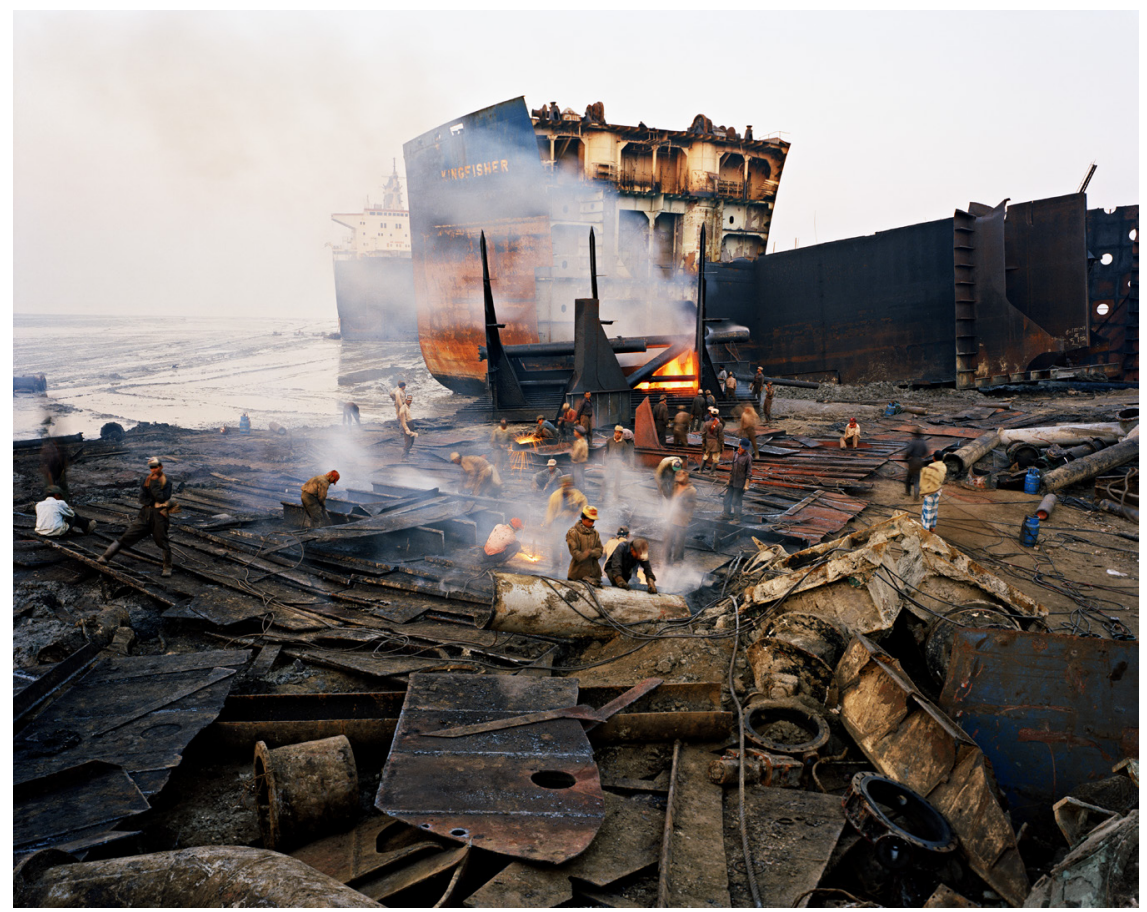

FIGURE 31. Edward Burtynsky, Shipbreaking \#11 (2000). ( Edward Burtynsky, courtesy of Nicholas Metivier Gallery, Toronto.

somewhere between 100,000 and 200,000 workers are involved in the Chittagong ship recycling industry, with similar numbers reported for India, and smaller but comparable figures for Pakistan and China.

Edward Burtynsky began photographing the shipbreaking practices in Pakistan and India in 2000, a year after international policies changed to reflect a more serious consideration of the disturbing effects of international oil spills. First there was the Exxon Valdez oil spill, one of the most devastating environmental disasters in human history. In 1989, the Exxon Valdez oil tanker destroyed 1,00o miles of shoreline in Alaska. ${ }^{57}$ But it was not until 1999, after the twenty-five-year-old single-hull tanker, Erika, leaked 10,000 tons of heavy oil into 250 miles of the Brittany coastline of France that the International Maritime Organization mandated that tankers built prior to 1974 be removed from service by $2003 . .^{58}$ In theory, 2,200 tankers would be scrapped by 2010. These ships can measure up to a thousand feet long, be twenty stories high, and weigh 25 million pounds. ${ }^{59}$

For those already in the industry, the new shipbreaking mandate was good news. One such beneficiary was the internationally respected Dr. Anil Sharma, president and CEO of Global Marketing Systems (GMS), based in Maryland, with 
offices in Dubai, Shanghai, and Singapore, with claims to being the "world's largest and only ISO 9001 (BV) certified cash buyer of ships for recycling." ${ }^{\circ 0}$ Sharma launched GMS in 1992 and is responsible for determining where a number of large oil tankers will end up. The company's website outlines the advantages of choosing the country best suited for breaking up a ship based on the needs and goal. Sharma reports delivering more than three hundred ships in a single year. ${ }^{61}$ The International Law and Policy Institute explains, "the shipping industry now faces tremendous financial challenges, and the risk that additional vessels will be sent to beaching has never been greater. Even Norwegian-listed companies made this choice in 2015." ${ }^{22}$ Since steel and other salvaged materials fuel developments in Pakistan, India, and Bangladesh, it is abundantly clear that what is "waste" to some is a "natural resource" to others (akin to the arbitrariness of signal versus noise, discussed in chapters 1 and 3$)^{63}$

Nonetheless, a number of problems simultaneously emerge. For one, a lot of this bulk material cannot be recycled at all. Second, an overwhelming number of unethical procedures are used to acquire ships and dismantle them, most notably the unethical treatment of the land and nonunionized, underrepresented workers involved. For example, each ship contains an average of 15,000 pounds of asbestos and ten to a hundred tons of lead paint, all of which end up on Asian coasts, where they have caused a significant degree of environmental damage to marine life, beaches, and fishing villages. ${ }^{64}$ Asbestos and lead waste have also negatively affected many of the children who go to work on these ships barefoot or wearing flip-flops and are expected to use hammers to break apart the asbestos in the ship (which they then shovel into bags, carry outside, and dump in the sand). ${ }^{65}$

One of the most neglected areas in existing environmental critiques of this industry is the treatment of human life as waste. Environmental scholars have traditionally construed waste and trash as something other than human, as noted in the Introduction, but Michelle Yates has recently disclaimed this legacy, demonstrating instead that in capitalism, the human is also utilized as a form of waste. ${ }^{66}$ This is in and of itself tragic, aside from the toxic materials people are asked to work with. Shipbreakers are expected to travel to remote locations to pursue whatever relatively minimal economic gain is available there and live in huts made of shipbreaking leftovers. At the turn of the millennium, India, Pakistan, and Bangladesh were home to 80 percent of the world's dirtiest and most dangerous jobs. ${ }^{67}$ The International Federation for Human Rights (FIDH) reported in 2009 that 25 percent of the workers on the beaches of Chittagong were children, often between the ages of 10 and 13, who worked twelve hours a day, seven days a week for wages under U.S.\$0.32 an hour. "Instead of raising wages or paying the proper overtime premium, yard management always holds back five days' wages - up to 1,200 taka ( $\$ 17.40$ ) to 'bond' the laborers to the yard. The fact that workers can be 'bonded' and held in the yard for just $\$ 17.40$ is an indication of how desperately poor and on the edge these workers are." ${ }^{\prime 6}$ 
It is also estimated between one and two thousand workers have been killed in Bangladesh's shipbreaking yards over the past thirty years. On average, a worker is seriously injured every day and one worker is killed every three to four weeks. ${ }^{69}$ Sometimes the number is higher. In November 2016, the BBC reported the death of eleven people in an explosion at a shipbreaking yard in southwestern Pakistan, while fifty-nine other workers were badly burned.70 "If there is a hell on earth, this is it," Charles Kernaghan says, executive director of the Institute for Global Labour and Human Rights..$^{71}$ Nevertheless, workers continue to arrive by the dozen, motivated by pay. A migrant farmer from northern Bangladesh can earn at least triple on the beach what he could back on the farm, making it worth the risk..$^{22}$

Burtynsky's unusually large-scale images of these shipbreaking practices, and those in related Chinese factories and e-waste sites, address these scenarios. In Burtynsky's China series, for example, many images seduce the viewer, despite an implicit, unavoidable cynicism in what the images depict. In one image from the series, workers are clad in identical pink and blue uniforms at the Deda Chicken Processing Plant in Dehui City, Jilin Province China (2005), revealing endlessly repeating shapes and colors by virtue of their sheer number. In one of the closing scenes of Jennifer Baichwal's 2006 documentary Manufactured Landscapes, in which the China series is discussed, we similarly see rows and rows of the workers identically clad in yellow and black lining up outside the Cankun Factory in Zhangzhou, Fujian Province, after work. The patterns created by their uniforms, echoing those of the buildings behind them, somehow render the image aesthetically pleasing. The uniformity and repetition make the images easy to understand graphically, but, as critics have suggested, is this enough to leverage a commentary on the exploitation of labor, life, and the environment?

Similar questions emerge in Burtynsky's Oil (1997-2009) series, a project that involved the artist's driving around the United States documenting automobile culture. ${ }^{73}$ In some of the images printed in the catalogue for the series, one finds a myriad of full-page, large-scale printed images, with beautiful colors and magnificent detail, but little context and no captions. The text and essays are located in the back of the book, as is also the case with his monographs Water (2009-13) and Quarries (2007, with photographs from the early 1990s), and portions of volumes published by independent galleries like Robert Koch in San Francisco and Sundaram Tagore in Los Angeles. Leafing through the first hundred pages of these exquisitely produced catalogues, and without knowing much about the background of any given project, one is forced to view the images unfairly, purely in terms of their surface aesthetic. As patterns and colors dazzle, they supersede any notion of fear or discomfort, gradually moving questions of context into the background of consciousness. This is also why, when first encountering Burtynsky's work, his photographs seem to fit in conventional "art photography" rubrics: an exclusive concern with primary and secondary light sources, composition, cropping, color, patterns, and abstraction, and indeed, he diligently and conscientiously 


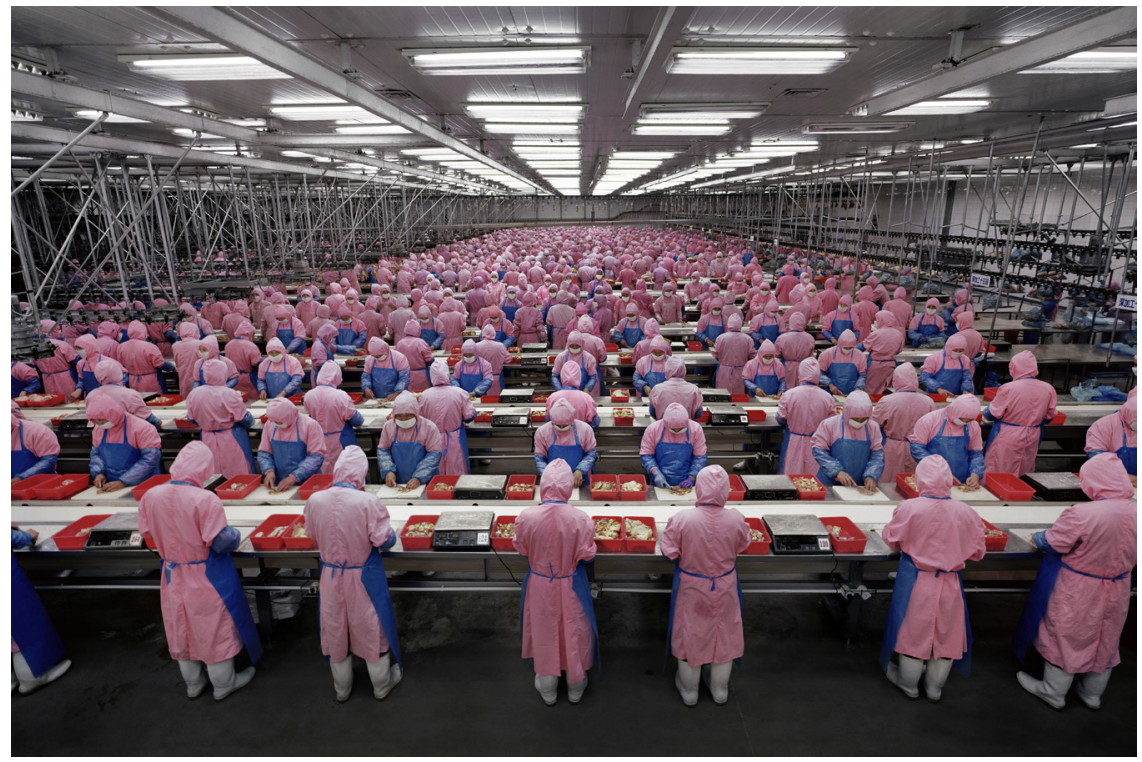

FIGURE 32. Edward Burtynsky, Manufacturing \#1, Deda Chicken Processing Plant, Dehui City, Jilin Province, China (2005). Digital chromogenic color print. () Edward Burtynsky, courtesy of Nicholas Metivier Gallery, Toronto

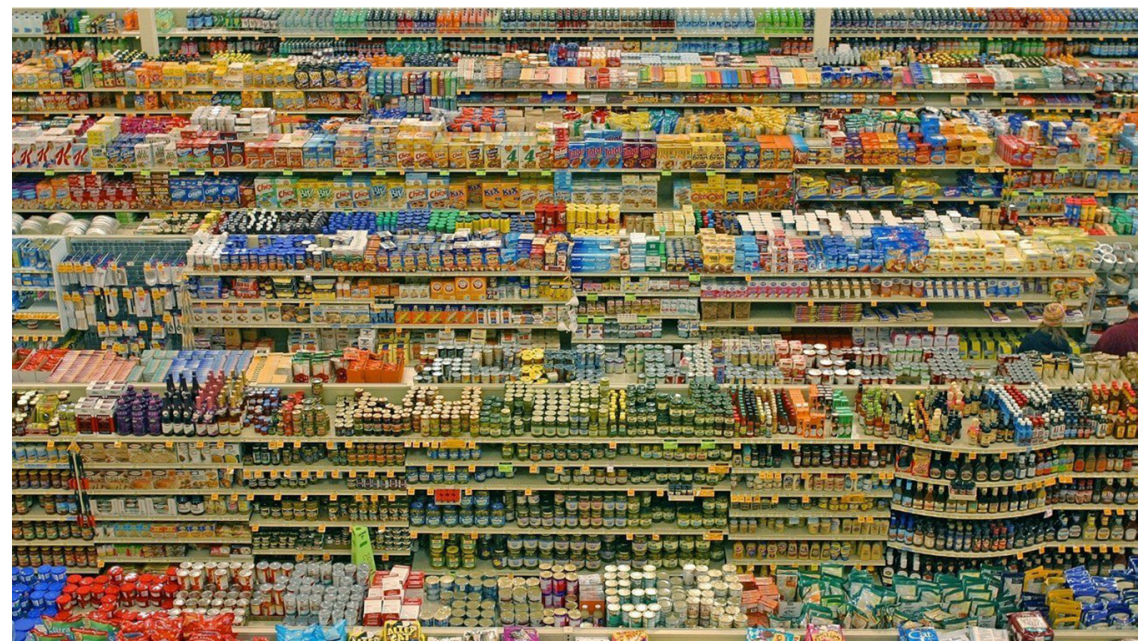

FIGURE 33. Godfrey Reggio, still from the film Koyaanisqatsi (1982), 35mm and 16mm film, 86 minutes. The colors of consumption are chaotic and organized. 
works with his large-format camera to achieve an uncompromising quality for each image.

Other documentary photographers have used similar approaches for depicting international crises across global landscapes. In cinema, the ecologically attuned yet highly stylized films of Godfrey Reggio or Ron Fricke invoke economic, political, and social turmoil portrayed through spectacularly phenomenal cinematographic art. Reggio is best known for his Qatsi trilogy, which includes the films Koyaanisqatsi (1982), Powaqqatsi (1988), and Naqoyqatsi ("Life as War," 2002), while Fricke is known for Baraka (1992), Chronos, (1985), and Sacred Site (1986), as well as for his innovative use of time-lapse photography and role as director of Koyaanisqatsi. What Reggio and Fricke do in cinema, Burtynsky's work does in art photography.

In the long tradition of landscape painting, artists have also developed approaches to the sublime by depicting tensions between beauty and waste. Thomas Cole's Course of Empire series (1836), Boetzkes points out, "traces the emergence and demise of an imagined city," 74 while J.W. Turner depicted beautifully dark, coal-polluted landscapes. Photographs documenting the atom bomb explosion in the Nevada desert and the somber beauty of blazing oil refineries at night also invoke this tension between visual beauty and environmental destruction. Arguably, this double-edged sword of beauty and terror cuts to one of the most persistent and pressing concerns of our time. ${ }^{75}$

We can now appreciate why critics have responded to Burtynsky's work as decontextualized modern art or mere spectacle. "But dang it's lovely," former Washington Post columnist David Segal concludes, while still conceding that Burtynsky's images of Bangladeshi shipbreakers may document the most dangerous worksite in the world. ${ }^{76}$ Gerda Cammaer likewise argues that Burtynsky creates "art," not social commentary. He "destabilizes the very ontological character of the photograph," she writes, "deflating the evidential real in favor of aesthetic value." For her, the triumph of the aesthetic ultimately deprives the work of "any other reading, be it an ecological, social or cultural." 77 Concluding her review of Burtynsky's 2002 show at the Charles Cowles Gallery, New York Times critic Margarett Loke writes "Mr. Burtynsky's pictures have a way of looking wonderful despite man's most determined tampering." ${ }^{8}$ And lastly, Meghan Bissonnette, in her assessment of Burtynsky's work, alongside J. Henry Fair's and David Maisel's, she writes, the "photographs provide an aestheticized and detached view of destruction." Burtynsky's manufactured landscapes, she continues, are "hauntingly beautiful. Despite their desire to raise awareness for environmental issues," they "evoke the detached gaze of contemporary ruin porn." 79

To be fair, Burtynsky unequivocally prioritizes the lush surface. At the same time, it would be hasty to conclude that his work is entirely void of criticality. Yes, he relies on classic techniques in symmetry, line, and the repetition of form first and foremost. Works like "Densified Oil Filters, \#1, Hamilton, Ontario," depict 
hundreds of neatly crushed oil filters tossed on a pile at random angles, each reflecting light from the rusted, silvery metal, but the harshness of the industrial context is still preserved. Jennifer Peeples makes comparisons between Burtynsky's work and Jackson Pollock's paintings, "with their abstraction of shapes and colors." Burtynsky's bright dots and colors punctuate the landscape in the way Pollock's black, white, red, yellow, and sometimes blue abstractions do, but in Burtynsky's work we can still identify the oil filters as oil filters. The same cannot be said of Pollock's total abstractions. Burtynsky's strategy plays with the ostensibly apolitical, but at the end of the day, it is undeniably rooted in the social and political sphere, not in its transcendental elimination.

In this way, notwithstanding the criticisms noted above, Burtynsky's work consistently and deliberately manufactures tensions that require us to rethink how we see what we see, whether consciously or not. According to Lori Pauli, Burtynsky is "cautious about applying the term 'beautiful' to his photographs." What interests him is "getting beyond the automatic response that equates manufacturing with ugliness and pollution." ${ }^{\text {"1 }}$ His aim is to invite people into the piece, to make it an "immersion experience where people say, 'I'm in here but I shouldn't like it.' I want to create that tension, have them attracted yet repulsed, to show them the dilemma we're in." ${ }^{82}$ No conclusion or solution is reached, and this is precisely the point: he leaves the viewer in a precarious standstill, akin to the stopping of the X-ray sublime outlined above. ${ }^{83}$

To return to Peeples' point, by granting affluent audiences access to previously unseen sites of environmental destruction and trash retrieval, he opens the door for a new form of self-reflection. ${ }^{84}$ How our waste accumulates and circulates is an issue of local and global concern. Heidegger once wrote, the "question concerning technology is never technological," rather, it is the questioning itself that matters. Questioning builds consciousness, a human consciousness that sees any "what" about machines and their waste as intrinsically connected to the how. In sum, to remain on the surface of the work-however beautiful it may be-is a disservice to it and the history and culture that shaped it. Burtynsky's images of metal and mine tailings, densified oil filters, scrap metal, and rebar production are beautiful, but they are far from the naive "landscape aesthetic of wilderness appreciation," as Joan Schwartz puts it. ${ }^{85}$

\section{CHINA'S E-WASTE}

Burtynsky's e-waste series, which began in China in 2002, further explores this ambiguous tension between light and dark, and beauty and terror. Like the Chittagong images, they seduce the eye with rich color, pattern, and detail while they are simultaneously haunted by a darker subtext.

In the first decade of the twentieth century, growth in the Chinese economy placed it on the international stage. The country thundered ahead in manufacturing, 


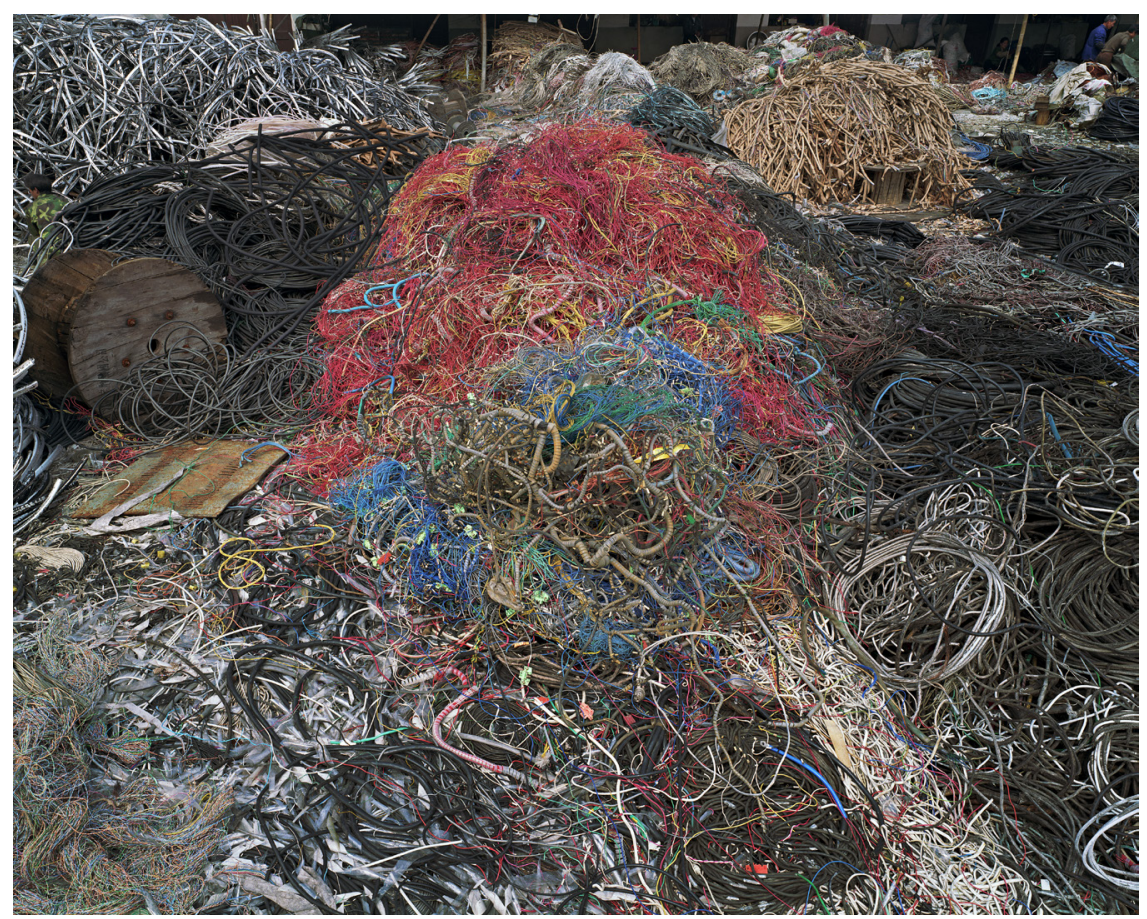

FIGURE 34. Edward Burtynsky, China Recycling \#07 (2004). Wire Yard, Wenxi, Zhejiang Province, China. Chromogenic print. The eye is drawn to the colored wires, seeking an organizing principle. () Edward Burtynsky, courtesy of Nicholas Metivier Gallery, Toronto.

recycling, shipbuilding, urban renewal, and in particular, the development of the Three Gorges Dam, one of the world's largest hydroelectric power projects. Burtynsky's China images address multiple aspects of the country's developments during this time. I focus here only on those depicting e-waste and related forms of high-tech recycling. ${ }^{86}$

Electronic waste ("e-waste") is one of the largest sources of toxic heavy metals in municipal and global dumps. ${ }^{87}$ In 2018 , almost fifty million metric tons of e-waste were estimated to be generated worldwide. ${ }^{88}$ Researchers at Carnegie Mellon concur, reporting that the amount of e-waste is growing three times faster than ordinary household trash. Even outdated statistics astound. In 1999, the National Safety Council predicted that between 1997 and 2007, more than 500 million computers would become obsolete in the United States alone, approximately 136,000 per day. The problem of e-waste disposal also remains acute, especially if the materials cannot be resold for profit. Burning them is sometimes proposed, but this has not yet been proven practical or safe. Open burning, for example, can create acid baths and toxic land dumps, exposing people to the poisons in the water and air, 


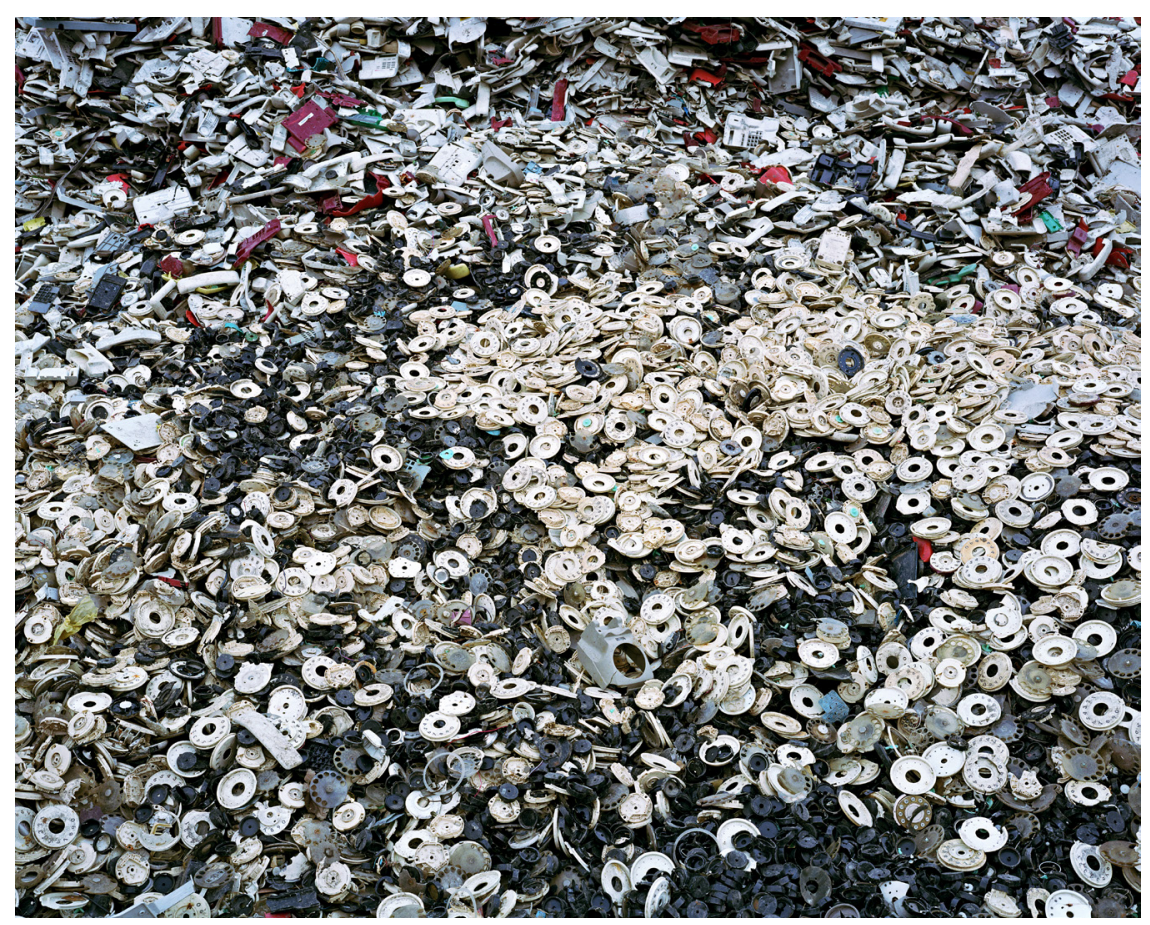

FIgURE 35. Edward Burtynsky, China Recycling \#05 (2004). Phone Dials, Zeguo, Zhejiang Province (2004). (๑) Edward Burtynsky, courtesy of Nicholas Metivier Gallery, Toronto.

including dioxins and furans. ${ }^{89}$ The use of "scrubbers and screens," Elizabeth Royte argues, could hypothetically catch many of these toxic emissions, but "scientists consider even minute quantities, once airborne, to be dangerous." 90 The next best option appears to be recycling, but this can be done economically with only a portion of these materials..$^{91}$ The remaining items are smashed up by laborers and the debris frequently accumulates in pools of toxic sludge, which itself finds its way into groundwater (tests on the soil and water in regions where this is done have revealed levels of lead, chromium, and barium a hundred times higher than those allowed by the U.S. and European environmental health standards). ${ }^{92}$

Like the shipbreakers in Bangladesh, many Chinese workers engage in dangerous activity without any protective gear, policy, or law. In 2002, researchers from Silicon Valley Toxics Coalition (SVTC) and the Basel Action Network (BAN) investigated and videotaped unprotected "men, women, and children" in the rural Chinese village of Guiyu "extracting copper yolks from monitors with chisels and hammers." Investigators observed the workers moving through a Wall•E-type landscape, maneuvering "swirling mixtures of hydrochloric and nitric acid" (a caustic, highly poisonous chemical) in open vats. ${ }^{93}$ Further research into ethical 
policies are urgently required, yet the United States, a leading producer of e-waste, has been exceedingly negligent about taking significant steps. "Rather than having to face the problem squarely," SVTC and BAN explain, "the United States and other rich economies that use most of the world's electronic products and generate most of the e-waste, have made use of a convenient, and until now, hidden escape valve-exporting the e-waste crisis to the developing countries of Asia." ${ }^{44}$

Any visual document of e-waste, therefore, cannot help but dissolve myths of unfettered technological progress, efficiency, and glistening utopias. But how does one do this elegantly and carefully without horrifying or shocking viewers or merely sensationalizing the surface qualities of a colorful image? Burtynsky's China Recycling \#7, Wire Yard, Wenxi, Zhejiang Province (2004), is one example as it carefully depicts plastic wires in multiple colors. The eye is first drawn to the red heap in the center of the composition, which casually merges with some yellows, and eventually blue and green plastic wires in the foreground, where seemingly arbitrarily colored wires are strewn across the earth. After a slightly prolonged viewing, the order becomes clear: a highly systematic, methodical process of recycling the e-waste is under way, reinforced as the eye wanders to the secondary and tertiary piles of bronze copper wires to the right and the silver-metallic and black piles of wires in the upper left and lower right. The same technique is used in other images in the series, including China Recycling \#5, Phone Dials, Zeguo, Zhejiang Province (2004) and China Recycling \#8, Plastic Toy Parts Guiyu, Guangdong Province (2004). In China Recycling \#5, one sees hundreds, possibly thousands, of black and silver circular metallic plates with little donut holes cut through the center. All of the pieces are exactly identical but through their seemingly random distribution throughout the pile, their pattern of difference and repetition offers the mind a pleasing sense of rhythm and coordination (again, the most basic form of optical delight). And then there is a double take: all of these many pieces of metal are from the interiors of rotary telephones, objects one will likely never encounter in the West again, but which pile up here as heaps of trash.

Similarly, in China Recycling \#8 Plastic Toy Parts, Guiyu (Guangdong Province, China, 2004) heaps of scrap plastic and metals are at first beautiful on a graphic level, gently accented with pink, red, yellow, and blue in a sea of silver, black, and grey. And then one notices the metallic fragments spilling into the nearby groundwater. As artifacts of a mechanical era almost forgotten by the developed world, these defunct, "dead" media return to haunt a one-sided historical consciousness. This leaves an unresolved tension between the visual beauty of the abstract color and the harsh global realities of the e-waste recycling it is sampled from. Likeminded images in the series include China Recycling \# 18, 20, and 24, all of Cankun Aluminum, Xiamen City, Fujian Province, and \# 12 from Ewaste Sorting, Zeguo, Zhejiang Province, 2004. As with Burtynsky's shipbreaking images, environmental toxins and rampant air pollution simultaneously appear as dark and beautiful. His images consistently straddle this dialectic between pleasing visual 


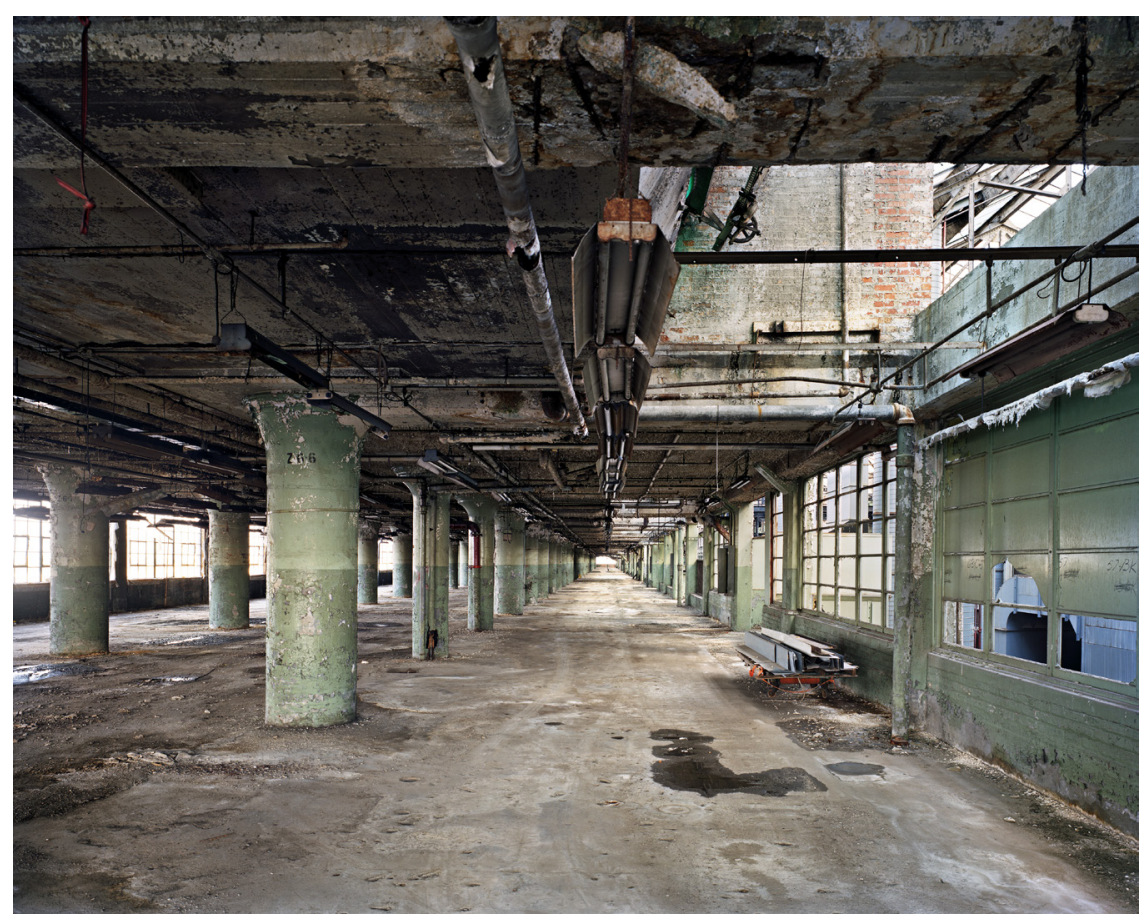

FIGURE 36. Edward Burtynsky, Ford's Highland Park Plant \#2 (2008). Assembly line corridor in a factory in Detroit, Michigan. Industrial ruins aestheticized to appear precious yet abandoned. (C) Edward Burtynsky, courtesy of Nicholas Metivier Gallery, Toronto.

pattern and the more disturbing context of e-waste and consumer excess, without offering any easy answers.

Burtynsky's 2008 Detroit images offer a variation on this dialectic between horror and awe. The series features the interiors and exteriors of abandoned automobile factories and warehouses in the city, speaking to the devastating economic downturn in the United States after 2007 , especially as it hit hard in cities like in Detroit. The Detroit images romanticize ruin, a claim only marginally applicable to the China and India images. Here, however, images transform industrial and urban failure into visual spectacle. ${ }^{95}$ And thus the question returns: Is Burtynsky using nostalgic beauty, as critics suggest, to alleviate guilt and shame at having failed to take responsibility for these industrial wastelands? Or, can such disturbing realities only ever be understood indirectly and partially, as Nietzsche famously argued, through metaphor and poetry? ${ }^{96}$ My opinion has already been divulged in the Introduction: beauty and dazzling surfaces (color, and color as noise) are required to digest otherwise uncomfortable truths. Furthermore, because the X-ray sublime leaves the final steps of aesthetic experience unresolved, 


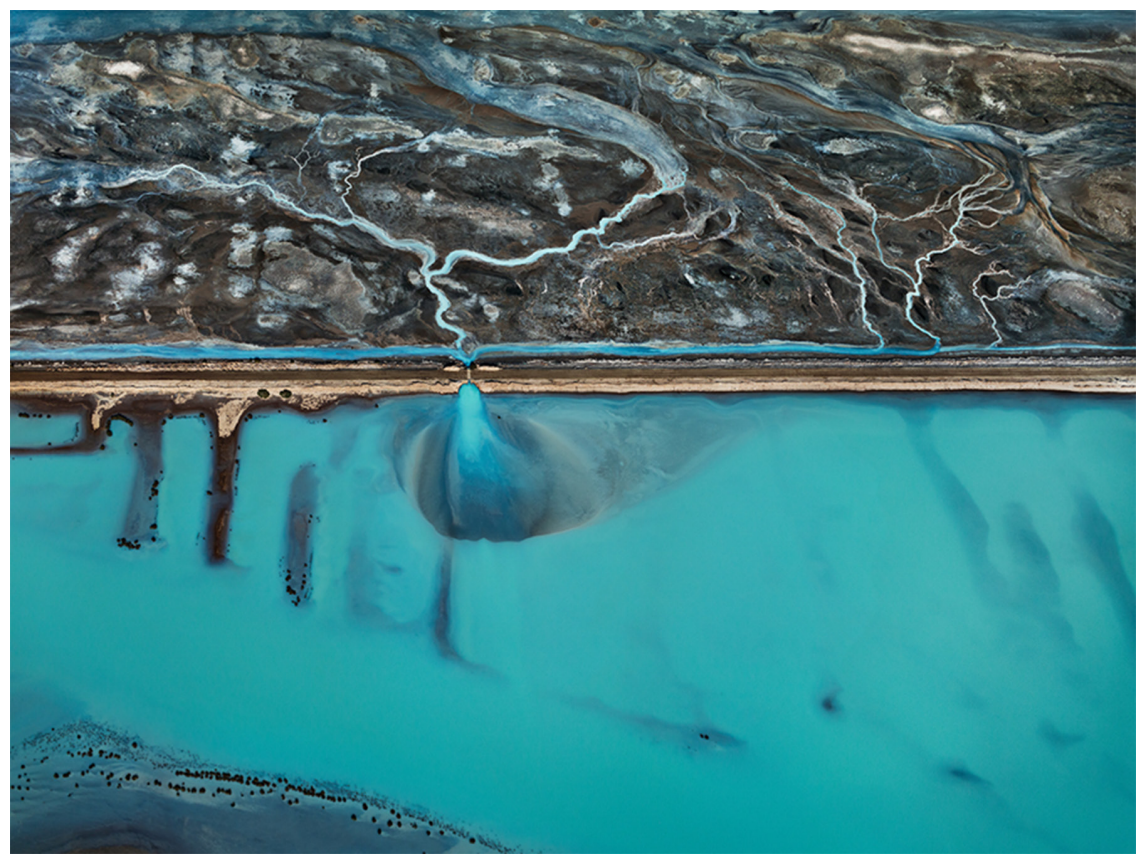

FIGURE 37. Jennifer Baichwal and Edward Burtynsky, Watermark (2013), 100 minutes. Documentary still. The aerial perspective stylizes the industrial landscape through abstraction and brilliant color.

a work becomes that much more susceptible to criticism as nonsensical fluff. A slew of critics have purported as much. Catherine Zuromskis, for one, argues that Burtynsky's images capture a "static beauty ... [a] landscape that simply cannot work: paralyzed, impossible."97 Likewise, Jill Gatlin concludes that the tension between anxiety and pleasure in Burtynsky's images of toxic and high-tech waste is so intense that it halts (and problematizes) direct political action. "The toxic sublime," she writes, "disturbs ... viewers' aesthetic sensibilities, not their identities as consumers, polluters, or political agents." ${ }^{\text {98 }}$ While I agree with these observations to the extent that Burtynsky's images halt the assumed teleology of classical aesthetic experience, I do not concede that the work is apolitical, even if the politics are covert. Burtynsky's failure to resolve the tension in the juxtaposition between a number of contrasting realities - the imagination and the understanding; beauty and ugliness; magnitude and insignificance; the known and the unknown-are a sign of the X-ray sublime's success. ${ }^{99}$ Left without easy answers or a prefabricated conclusion, the images stare back at us, like Brecht's direct gaze. Their impossibility implicates us, not just "them." The beautiful pictures ask us: Can you look at this peacefully, undisturbed? And even if the answer is yes, then the image has at least done the work of raising the question. 


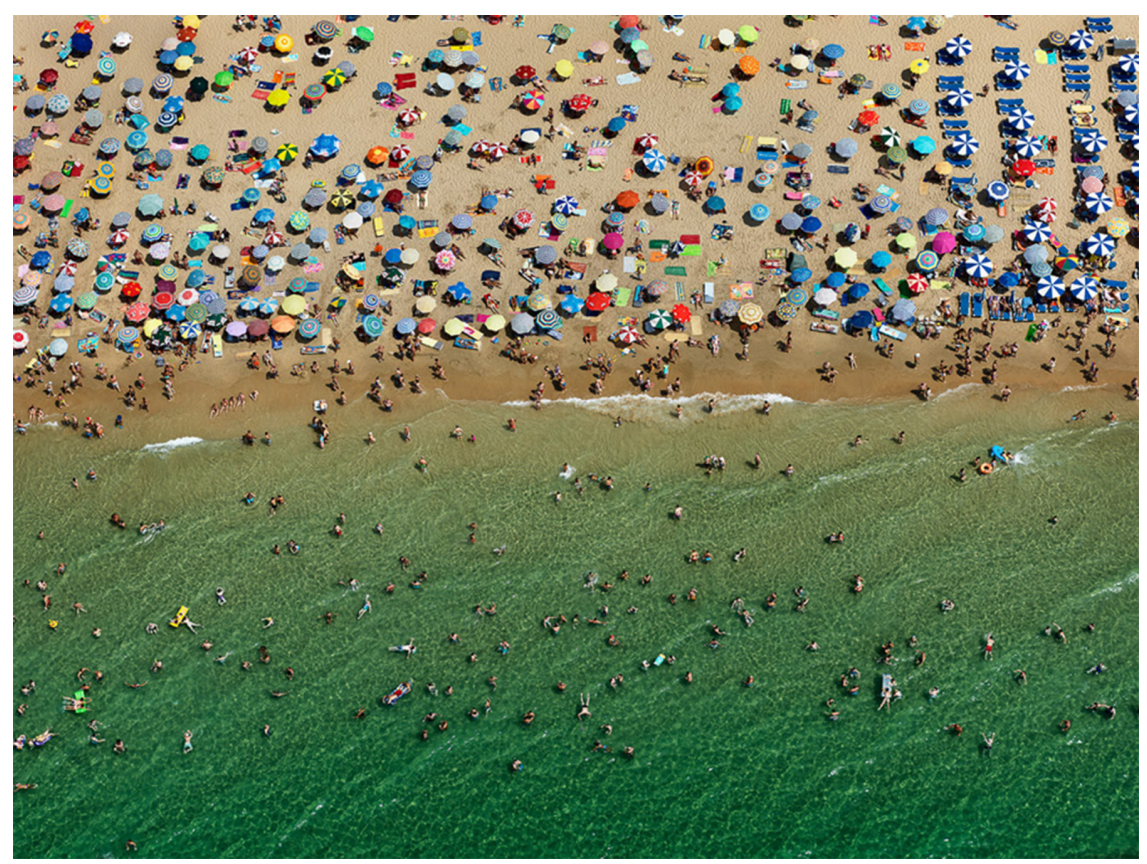

FIGURE 38. Edward Burtynsky, Benidorm \#1, Spain, 2010. Still from Jennifer Baichwal and Edward Burtynsky, Watermark (2013).

\section{AERIAL PERSPECTIVES ON THE X-RAY SUBLIME}

In the 1930s, the French photographer Henri Cartier-Bresson complained about conventional landscape photography. "The world is going to pieces," he exclaimed, "and people like [Ansel] Adams and [Edward] Weston are photographing rocks!"100 Taking a stab at their ostensibly irrelevant, apolitical, and non-technological "Nature" aesthetic, which persists across historical eras, Cartier-Bresson was drawn instead to the modern consciousness made possible through new tools and techniques. Like-minded photographers concurred, even August Sander and Carleton Watkins, who had been imaging landscapes since the nineteenth century, had begun to eschew the idealized nature aesthetic. It is not surprising that both Sander's and Watkins's innovative works were largely influential to Burtynsky. When first encountering Sander's Quarry Pit (1925-35) at the National Gallery of Canada in 1982, an image of a gigantic hollow cavity inside of a rock quarry, Burtynsky recalls a delightful confusion, "I stared at it for a minute before I could figure out what I was looking at." ${ }^{{ }^{101}} \mathrm{He}$ was similarly riveted when he first encountered a Watkins print at the Metropolitan Museum in New York in the early 1980s. Unlike traditional approaches to landscape, Watkins's work hovered over a mythical, archetypal world from an oddly elevated perspective, intentionally distancing 
itself from its depicted object. ${ }^{102}$ Since 2008, Burtynsky has used emergent media (helicopters, digital lighting and photographic equipment) to create aerial images that continue to abstract from conventional approaches to the landscape. Anthropocene: The Human Epoch (2018) and Water (2013), illustrate these methods as the artist images the earth from thousands of feet above, widening the already precarious gap between human and world. ${ }^{103}$

This chapter has only scratched the surface of the many crises of e-waste. Egypt's "Garbage City" and the Long Island Fresh Kills landfill both evoke a horror and beauty akin to the X-ray sublime, with nothing of the transcendental or divine to speak of, a sobering moment of realization that forces a reconnection to the body, earth, and world. This waste is our waste. Paul Virilio once suggested adopting a "Gray Ecology" where "aesthetic pollution ... doesn't mean that it's ugly, or that it's beautiful. It means that it interferes." ${ }^{104}$ The troubled beauty of the X-ray sublime does just this-like noise and abstract color-by shattering delusions of transparency and unfettered success.

In the next chapter I draw on Kant's notion of the mathematical sublime to further explore how computer-generated images of trash and waste figure in depictions of ecological breakdown. 